\title{
PERBANDINGAN DAN TREND KINERJA KEUANGAN BPRS SELAMA LINKAGE PROGRAM DENGAN BANK SYARIAH PERIODE 2011 - 2016 (STUDI KASUS BPRS BAKTIMAKMUR INDAH, BPRS BHAKTI SUMEKAR, DAN BPRS PNM MENTARI)1)
}

\author{
Muchamad Ichwan Subagiyo \\ Mahasiswa Program Studi Ekonomi Islam-Fakultas Ekonomi dan Bisnis-Universitas Airlangga \\ Email: muchamad.ichwan-13@feb.unair.ac.id
}

Dina Fitrisia Septiarini

Departemen Ekonomi Syariah-Fakultas Ekonomi dan Bisnis-Universitas Airlangga

Email: dina.fitrisia@feb.unair.ac.id

\begin{abstract}
The research aims to discover whether there are any differences in financial performance between Sharia Rural Bank (SRB) which take part in the linkage program and this study was to determine the trend of financial performance in period 2011-2016. The method used in this research is quantitative. The sample were SRB Baktimakmur Indah, SRB Bhakti Sumekar and SRB PNM Mentari and then carried out the analysis different test using ANOVA and Kruskal Wallis test. The variables used in financial performance assessment are ROA, ROE, BOPO, NPF, FDR, and CAR. The data used for this study are secondary data gathered from financial report. Trend analysis of this research showed that SRB Bhakti Sumekar have a good growth in ratio of ROA, ROE, BOPO, NPF and FDR, but SRB Baktimakmur have the most growth in ratio of CAR. Differences in financial performance viewed from ROE, BOPO, NPF, FDR, CAR. But, ROA do not any differences.
\end{abstract}

Keywords: Trend Analysis, Comparative Financial Performance, Linkage program, Sharia Rural Bank.

\section{Pendahuluan}

Perbankan Syariah mulai muncul

Indonesia, hal tersebut dikarenakan seiring dengan kebutuhan masyarakat untuk melakukan setiap kegiatan transaksi kevangan secara halal dan sesuai syariat Islam. Menurut Ismail (2011:33), peran Perbankan Syariah dalam aktivitas ekonomi Indonesia tidak jauh berbeda dengan perbankan konvensional, perbedaan mendasar dari keduanya terdapat pada prinsip-prinsip dalam transaksi keuangan atau operasional yang dilakukan. Pelaksanaan kegiatan operasional Bank Syariah harus terbebas dari sistem bunga atau riba yang dilarang dan digantikan dengan sistem bagi hasil. Luasnya wilayah Indonesia menyebabkan pelayanan perbankan tidak dapat dirasakan secara merata oleh masyarakat adanya keterbatasan cakupan wilayah pelayanan perbankan.

Permasalahan diatas menjadi penyebab munculnya suatu lembaga keuangan yang dapat menjangkau wilayah yang tidak bisa dijangkau oleh perbankan, lembaga keuangan tersebut dikenal sebagai Bank Perkreditan Rakyat (BPR). BPR dikenalkan pertama kali oleh Bank Rakyat Indonesia (BRI) pada akhir tahun 1977, ketika BRI mulai menjalankan tugasnya sebagai Bank Pembina Lumbung Desa, Bank Pasar, Bank Desa, Bank Pegawai dan Bank-Bank sejenis lainnya. Pada masa pembinaan yang dilakukan oleh BRI, seluruh bank tersebut diberi nama Bank Perkreditan Rakyat.

1) Jurnal ini merupakan bagian dari skripsi Muchamad Ichwan Subagiyo, NIM: 041311433042 , yang diuji pada 16 februari 2017. 
Subagiyo, et al/Jurnal Ekonomi Syariah Teori dan Terapan Vol. 5 No. 1 Januari 2018: 32-48;

PERBANDINGAN DAN TREND KINERJA KEUANGAN BPRS SELAMA LINKAGE PROGRAM DENGAN BANK SYARIAH PERIODE 2011 - 2016 (STUDI KASUS BPRS BAKTIMAKMUR INDAH, BPRS BHAKTI SUMEKAR, DAN BPRS PNM MENTARI) Kegiatan usaha yang dilakukan BPR salah satunya adalah memberikan kredit untuk Usaha Mikro, Kecil dan Menengah (Ismail, 2014).

Munculnya BPR pada tahun 1977 dirasa belum cukup memenuhi kebutuhan masyarakat yang ingin melakukan pembiayaan sesuai dengan perintah Allah SWT dan juga terbebas dari unsur riba. Oleh sebab itu, pada 8 Oktober 1990 muncul Bank Pembiayaan Rakyat Syariah (BPRS) yang digunakan sebagai alternatif bagi masyarakat yang ingin melakukan pembiayaan sesuai dengan perintah Allah SWT, sesuai aturan syariat Islam dan bebas dari unsur riba. BPRS yang pertama kali berdiri adalah PT. BPRS Dana Mardhatillah, PT. BPRS Berkah Amal Sejahtera, dan PT. BPRS Amanah Rabbaniyah. Ketiga BPRS tersebut telah mendapat ijin dari Menteri Kevangan RI dan mulai beroperasi tanggal 19 Agustus 1991 (Ismail, 2014).

Menurut UU No. 21 tahun 2008 tentang Perbankan Syariah, penyaluran dana oleh BPRS berupa pembiayaan dengan akad transaksi bagi hasil, sewa menyewa, jual beli, pinjam meminjam, dan sewa menyewa jasa (multijasa). Penerapan prinsip syariah dalam BPRS tidak hanya sekedar dalam hal pembiayaan kepada Usaha Mikro Kecil Menengah (UMKM), terkhusus pada daerah-daerah kecil seperti desa, yang memang pada daerah tersebut dianggap masih banyak masyarakat yang membutuhkan pembiayaan. Dalam merealisasikan dukungan pada UMKM di Indonesia, Bank Konvensional maupun BUS melakukan pemerataan distribusi pembiayaan pada lembaga keuangan lain yang cakupannya lebih kecil dan letaknya lebih dekat dengan masyarakat, terutama yang berada di pelosok-pelosok wilayah Indonesia. Lembaga keuangan lain yang dimaksud adalah lembaga perantara penyalur pembiayaan yang terdiri dari BPR/BPRS, koperasi/KJKS. BPRS mempunyai fungsi pelayanan dengan jangkauan yang lebih luas kepada masyarakat. Dalam upaya pencapaian tujuan tersebut, Bank Indonesia membuat program bernama linkage program.

Berdasarkan Generic Model Linkage Program Bank Indonesia (2004), linkage program adalah program pembiayaan yang bersifat kemitraan, dalam program ini Bank Umum atau BUS mengeluarkan pembiayaan ke sektor UMKM secara tidak langsung, pembiayaan tersebut disalurkan melalui BPR atau BPRS. Linkage program dilakukan karena adanya permasalahan dalam pengelolaan dana yang dimiliki oleh BUS dan BPRS. BUS memiliki kelebihan dana untuk dikelola sementara alokasi pembiayaannya terbatas, di lain pihak BPRS memiliki kekurangan dana kelolaan sementara alokasi pembiayaanya cukup besar. Pola penyaluran linkage program dibagi menjadi 3, yakni executing, channeling, dan joint financing. Keuntungan dari linkage program ini adalah Pihak Bank mendapatkan kemudahan akses terhadap penyaluran 
Subagiyo, et al/Jurnal Ekonomi Syariah Teori dan Terapan Vol. 5 No. 1 Januari 2018: 32-48;

PERBANDINGAN DAN TREND KINERJA KEUANGAN BPRS SELAMA LINKAGE PROGRAM

DENGAN BANK SYARIAH PERIODE 2011 - 2016 (STUDI KASUS BPRS BAKTIMAKMUR INDAH, BPRS

BHAKTI SUMEKAR, DAN BPRS PNM MENTARI)

kredit pada UMKM dan BPRS

mendapatkan keuntungan dari

ketersediaan dana untuk disalurkan pada

debitur. Konsep kerjasama ini sesuai

dengan anjuran Allah SWT yang dituliskan

di Al-Qur'an pada Surat As-Sad ayat 24, dibawah ini:

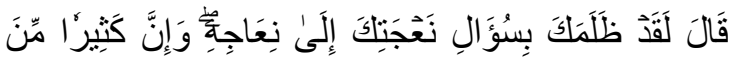

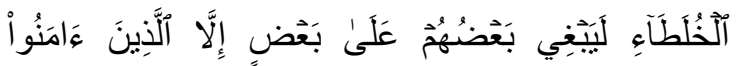

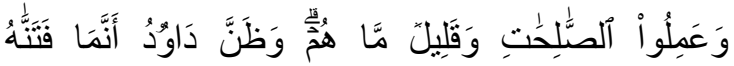

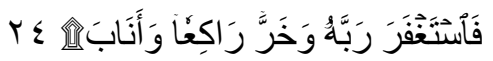

Artinya: "Sesungguhnya Dia telah berbuat zalim kepadamu dengan meminta kambingmu itu untuk ditambahkan kepada kambingnya. dan Sesungguhnya kebanyakan dari orang-orang yang berserikat itu sebahagian mereka berbuat zalim kepada sebahagian yang lain, kecuali orang-orang yang beriman dan mengerjakan amal yang saleh; dan Amat sedikitlah mereka ini". dan Daud mengetahui bahwa Kami mengujinya; Maka ia meminta ampun kepada Tuhannya lalu menyungkur sujud dan bertaubat.

$$
\text { Munculnya linkage program }
$$

diharapkan membawa dampak baik bagi pemerataan kondisi ekonomi masyarakat. Kinerja yang dilakukan oleh BPRS sangat menentukan sukses tidaknya penyaluran linkage program kepada UMKM. Penelitian ini dimaksudkan secara khusus untuk mengetahui perkembangan kinerja keuangan BPRS selama menggunakan linkage program dan untuk mengetahui ada tidaknya perbedaan kinerja keuangan yang dilakukan oleh BPRS Baktimakmur Indah, BPRS Bhakti Sumekar dan BPRS PNM Mentari selama menggunakan linkage program periode September 2011-September

2016.

BPRS tersebut dikarenakan BPRS tersebut merupakan BPRS yang masih menggunakan linkage program mulai dari tahun 2011-2016 terlihat pada laporan kevangan BPRS yang dipublikasi dalam website resmi Bank Indonesia, terdapat dana dalam pos penerusan dana mudharabah muqayyadah (chanelling), dana tesebut merupakan dana linkage yang masih berada di nasabah dan belum kembali ke BPRS mulai periode September 2011-September 2016 (www.bi.go.id, diakses 23 Oktober 2016).

Berdasarkan hasil wawancara dan data laporan kevangan BPRS terkait, komposisi pembiayaan dari dana linkage terhadap total pembiayaan lebih dari $50 \%$, hal tersebut dikarenakan dana linkage memiliki tingkat bagi hasil yang lebih rendah dibandingkan dengan deposito dan simpanan lainnya, sehingga lebih menguntungkan BPRS, yang tersebar dalam beberapa pembiayaan seperti murabahah, mudaharabah, musyarakah, ijarah dan qardh sesuai dengan kebutuhan nasabah BPRS (www.bi.go.id, diakses 23 Oktober 2016).

Berdasarkan penjelasan mengenai fungsi BPRS dan keberadaan linkage program, hal itu mendorong peneliti untuk mendalami lebih lanjut mengenai dampak linkage program terhadap kinerja keuangan BPRS. Peneliti berusaha mengamati, apakah linkage program sudah memberikan dampak positif atau belum pada kinerja keuangan BPRS. 
Subagiyo, et al/Jurnal Ekonomi Syariah Teori dan Terapan Vol. 5 No. 1 Januari 2018: 32-48;

PERBANDINGAN DAN TREND KINERJA KEUANGAN BPRS SELAMA LINKAGE PROGRAM DENGAN BANK SYARIAH PERIODE 2011 - 2016 (STUDI KASUS BPRS BAKTIMAKMUR INDAH, BPRS BHAKTI SUMEKAR, DAN BPRS PNM MENTARI) Kinerja keuangan BPRS dikatakan baik jika kegiatan penyaluran dana yang dilakukan berlangsung sesuai dengan aturan yang berlaku dan juga tanpa mengalami permasalahan. Hal itu didukung dengan fungsi diadakannya linkage program itu sendiri yaitu sebagai sarana bantuan dana dari Bank Umum Syariah untuk disalurkan kepada sektor rill melalui BPRS (Generic Model Linkage Program Bank Indonesia, 2004).

Pada pengamatan ini, penilaian kinerja keuangan menjadi bagian yang sangat penting. Pada laporan keuangan BPRS akan tersaji laporan neraca, laporan laba rugi, laporan komitmen dan kontijensi, laporan kualitas aktiva produktif dan informasi lainnya, sumber dan penggunaan ZIS, sumber dan penggunaan Qardhul Hasan, distribusi bagi hasil, dan perubahan dana investasi terikat.

Oleh karena itu, penelitian ini bermaksud untuk melakukan analisis Trend terhadap kinerja keuangan BPRS selama menggunakan linkage program dan membandingkan kinerja keuangan BPRS selama menggunakan linkage program, hal tersebut dilakukan untuk mengetahui bagaimana dampak dari adanya linkage program terhadap kinerja keuangan BPRS dan juga medapat BPRS terbaik yang dapat dijadikan referensi dalam mengelola dana linkage. Dari keterangan tersebut, peneliti mengambil judul "Analisis Trend dan Perbandingan Kinerja Keuangan Bank Pembiayaan Rakyat Syariah (BPRS) Selama Menggunakan Linkage program periode September 2011-September 2016 (Studi kasus pada BPRS Baktimakmur Indah, BPRS Bhakti Sumekar, dan BPRS PNM Mentari)."

\section{Landasan Teori}

Menurut UU No. 21 tahun 2008 tentang Perbankan Syariah, pengertian Bank Pembiayaan Rakyat Syariah (BPRS) adalah bank pembiayaan yang dalam sistem operasionalnya tidak memberikan jasa dalam lalu lintas pembayaran. Oleh sebab itu, Bank Pembiayaan Rakyat Syariah (BPRS) tidak diperbolehkan menawarkan jasa giro wadiah dan hal inilah yang memberikan perbedaan Bank Pembiayaan Rakyat Syariah (BPRS) dengan Bank Umum Syariah (BUS) dan Unit Usaha Syariah (UUS).

Menurut Ismail (2011:54), fungsi Bank Pembiayaan Rakyat Syariah (BPRS) pada umumnya adalah menghimpun dana dari masyarakat dan menyalurkan dana tersebut dalam bentuk pembiayaan kepada masyarakat yang dinilai membutuhkan suatu pembiayaan. Segala kegiatan penghimpunan dana maupun penyaluran dana didasarkan oleh suatu akad yang ada dari produk-produk yang dipilih oleh nasabah/masyarakat.

Selain bertindak sebagai pihak yang melakukan penghimpunan dana dari masyarakat dan menyalurkannya kepada masyarakat yang membutuhkan dana, dalam UU No. 21 Tahun 2008 pasal 4 ayat 2 dan 3 juga menjelaskan bahwa bank syariah dalam hal ini adalah Bank 
Subagiyo, et al/Jurnal Ekonomi Syariah Teori dan Terapan Vol. 5 No. 1 Januari 2018: 32-48;

PERBANDINGAN DAN TREND KINERJA KEUANGAN BPRS SELAMA LINKAGE PROGRAM DENGAN BANK SYARIAH PERIODE 2011 - 2016 (STUDI KASUS BPRS BAKTIMAKMUR INDAH, BPRS BHAKTI SUMEKAR, DAN BPRS PNM MENTARI) Pembiayaan Rakyat Syariah (BPRS) dapat melaksanakan fungsi sosial dalam bentuk lembaga baitul maal, yaitu menerima dana yang berasal dari zakat, infaq, sedekah, hibah dan dana sosial lain dan menyalurkannya kepada organisasi pengelola zakat.

Berdasarkan Peraturan Menteri Negara Koperasi dan UKM Republik Indonesia Nomor 03/Per/M.KUMKM/III/2009 tentang Pedoman Umum Linkage Program antara Bank Umum dengan Koperasi. Linkage program adalah suatu program kerjasama antara bank umum termasuk bank umum peserta Kredit Usaha Rakyat (KUR) dengan koperasi dalam rangka upaya meningkatkan akses pembiayaan UMK.

Linkage program mempunyai tujuan untuk mengatasi masalah lembaga keuangan mikro yang dianggap hingga saat ini cenderung kekurangan dana, namun memiliki nasabah potensial yang cukup besar. Linkage program mulai terorganisasi dengan baik ketika Bank Indonesia meluncurkan Arsitektur Perbankan Indonesia (API) pada tahun 2004 dan linkage menjadi salah satu program dalam pilar satu API. Selain itu, kelvarnya Generic Model Linkage program menjadikan aturan-aturan pelaksanaan linkage menjadi lebih jelas, seperti adanya persyaratan minimum BPRS peserta linkage, munculnya 3 skim linkage yang terdiri atas executing, channeling, dan joint financing. Adanya linkage program diharapkan dapat mendorong kinerja BPRS dalam menyalurkan kredit atau pembiayaan kepada masyarakat.

Penilaian kinerja keuangan adalah suatu hal yang penting untuk dilakukan, penilaian kinerja keuangan bertujuan untuk mengetahui kinerja pihak manajemen BPRS apakah telah beroperasi secara efektif dan efisien baik dari kegiatan penghimpunan dana maupun dari penyaluran dana. Penilaian kinerja keuangan BPRS dapat dilakukan dengan analisis terhadap laporan keuangan BPRS. Laporan keuangan adalah laporan yang menunjukkan kondisi kevangan perusahaan pada saat ini atau dalam suatu periode tertentu (Kasmir, 2013:7).

Analisis terhadap laporan kevangan dalam penelitian ini dilakukan dengan dengan menggunakan analisis Trend dan analisis rasio kinerja keuangan dari BPRS Baktimakmur Indah, BPRS Bhakti Sumekar, dan BPRS PNM Mentari. Menurut Mahmudi (2010:89) analisis trend adalah analisis yang dilakukan untuk mengetahui kecenderungan baik berupa kenaikan atau penurunan kinerja selama kurun waktu tertentu.

Analisis rasio kinerja keuangan pada penelitian ini menggunakan rasio ROA, ROE, BOPO, NPF, FDR, dan CAR. Rasio Return On Asset (ROA) digunakan untuk mengukur kemampuan manajemen Bank dalam memperoleh laba secara keseluruhan. Semakin tinggi ROA suatu bank, maka semakin besar juga tingkat keuntungan dan posisinya dianggap baik 
Subagiyo, et al/Jurnal Ekonomi Syariah Teori dan Terapan Vol. 5 No. 1 Januari 2018: 32-48;

PERBANDINGAN DAN TREND KINERJA KEUANGAN BPRS SELAMA LINKAGE PROGRAM DENGAN BANK SYARIAH PERIODE 2011 - 2016 (STUDI KASUS BPRS BAKTIMAKMUR INDAH, BPRS BHAKTI SUMEKAR, DAN BPRS PNM MENTARI) dari segi penggunaan aset (Dendawijaya, 2003:120).

Menurut Surat Edaran Bank Indonesia No. 9/24/DPbS tahun 2007, rasio Return On Equity (ROE) digunakan untuk mengukur kemampuan Bank dalam menghasilkan laba dengan menggunakan ekuitasnya. Menurut Surat Edaran Bank Indonesia No. 9/24/DPbS tahun 2007, rasio Beban Operasional Pendapatan Operasional (BOPO) bertujuan untuk mengukur tingkat efisiensi dan kemampuan bank dalam melakukan kegiatan operasionalnya sebagai penghimpun dan penyalur dana masyarakat.

Menurut Surat Edaran BI No. 3/30/DPNP tanggal 14 Desember 2001 menyatakan bahwa Non Performing Financing (NPF) adalah rasio keuangan yang menggambarkan besarnya tingkat pembiayaan bermasalah terhadap total pembiayaan. Financing to Deposit Ratio (FDR) adalah perbandingan antara pembiayaan yang diberikan oleh bank dengan dana pihak ketiga yang berhasil dikumpulkan oleh bank (Rivai dan Arifin, 2010:784). Menurut Surat Edaran Bank Indonesia No. 9/24/DPbS tahun 2007 Capital Adequacy Ratio (CAR) adalah rasio yang digunakan untuk menganalisis faktor permodalan, analisis dilakukan dengan membandingkan modal sendiri dengan aktiva tertimbang menurut risiko (ATMR). Analisis rasio keuangan merupakan metode analisis yang sering dipakai karena merupakan metode yang paling cepat untuk mengetahui kinerja keuangan suatu perusahaan.

Kinerja menunjukkan sesuatu yang berhubungan dengan kekuatan serta kelemahan suatu perusahaan. Kekuatan tersebut dipahami agar dapat dimanfaatkan dan kelemahan pun harus diketahui agar dapat dilakukan langkahlangkah perbaikan. Selain itu, adanya linkage program diharapkan dapat mendorong kinerja BPRS dalam menyalurkan pembiayaan kepada masyarakat dan dapat menunjang kemajuan dan peningkatan keadaan ekonomi masyarakat.

\section{Metode Penelitian}

\section{Pendekatan Penelitian}

Pendekatan yang digunakan dalam penelitian ini adalah pendekatan kuantitatif. Pendekatan kuantitatif digunakan karena penelitian ini dilakukan untuk menguji hipotesis dan membuktikan asumsi sebelumnya dengan menggunakan data terukur, sehingga dapat menghasilkan kesimpulan yang dapat dipertanggung jawabkan. Teknik analisis yang digunakan adalah statistik deskriptif, yaitu teknik statistik yang digunakan untuk menganalisis data dengan cara mendeskripsikan atau menggambarkan data yang telah terkumpul sebelumnya (Anshori dan Iswati, 2009:116).

\section{Identifikasi Variabel}

Variabel penelitian pada dasarnya adalah sesuatu yang berbentuk apa saja 
Subagiyo, et al/Jurnal Ekonomi Syariah Teori dan Terapan Vol. 5 No. 1 Januari 2018: 32-48;

PERBANDINGAN DAN TREND KINERJA KEUANGAN BPRS SELAMA LINKAGE PROGRAM DENGAN BANK SYARIAH PERIODE 2011 - 2016 (STUDI KASUS BPRS BAKTIMAKMUR INDAH, BPRS BHAKTI SUMEKAR, DAN BPRS PNM MENTARI) yang ditetapkan oleh peneliti untuk dipelajari, sehingga diperoleh informasi tentang hal tersebut, kemudian ditarik kesimpulannya (Sugiyono, 2000) dalam Anshori, dan Iswati (2009:57). Berdasarkan rumusan masalah, maka variabel dalam penelitian ini adalah (1) Return on Asset (ROA), (2) Return on Equity (ROE), (3) Beban Operasional Pendapatan Operasional (BOPO), (4) Non Performing Financing (NPF), (5) Financing to Deposit Ratio (FDR), (6) Capital Adequacy Ratio.

\section{Jenis dan Sumber Data}

Data yang digunakan dalam penelitian ini adalah data laporan keuangan triwulanan 30 September 2011 30 September 2016. Variabel yang digunakan dalam penelitian ini berupa rasio yang telah dipublikasikan dari pihak BPRS Baktimakmur Indah, BPRS Bhakti Sumekar, dan BPRS PNM Mentari.

\section{Sampel}

Sampel pada penelitian ini diambil dengan metode purposive sampling karena ada pertimbangan tertentu. Sampel yang diambil sebanyak 3 BPRS, ketiga BPRS tersebut merupakan BPRS yang mengikuti linkage program antara lain BPRS Baktimakmur Indah, BPRS Bhakti Sumekar, dan BPRS PNM Mentari.

\section{Prosedur Pengumpulan Data}

Prosedur pengumpulan data yang dilakukan peneliti adalah sebagai berikut:

1. Metode pengumpulan data langsung Metode ini dilakukan untuk memastikan keikutsertaan ketiga BPRS terkait dalam linkage program, hal tersebut dilakukan

dengan melakukan wawancara dengan pihak ketiga BPRS terkait.

2. Metode pengumpulan tidak langsung Metode ini dilakukan dengan mengumpulkan data laporan keuangan triwulanan dari ketiga BPRS periode 30 September 2011-30 September 2016 yang diambil dari website resmi OJK, dan Bank Indonesia. Selain itu, data-data mengenai ketiga BPRS tersebut juga didapat dari website resmi ketiga BPRS tersebut.

3. Metode studi kepustakaan

Metode ini dilakukan dengan mempelajari berbagai jurnal, buku pustaka, dan artikel yang digunakan untuk memahami permasalahan dan mendapatkan alternatif pemecahan masalah yang ada.

\section{Teknik Analisis}

Teknik analisis data dalam penelitian kuantitatif ini menggunakan analisis statistik, yang dilakukan melalui analisis trend rasio kinerja keuangan ketiga BPRS linkage program pada periodeperiode yang diteliti, analisis trend dilakukan dengan membandingkan rasio kinerja keuangan dari BPRS Baktimakmur Indah, BPRS Bhakti Sumekar, dan BPRS PNM Mentari dari waktu ke waktu dengan menggunakan tahun dasar.

Analisis data dalam penelitian ini menggunakan dua tahap, yakni statistik deskriptif dan statistik inferensial. Analisis statistik deskriptif adalah statistik yang digunakan untuk menganalisis data dengan cara mendeskripsikan data yang telah terkumpul sebagaimana adanya (Anshori dan Iswati, 2009:116). Statistik 
Subagiyo, et al/Jurnal Ekonomi Syariah Teori dan Terapan Vol. 5 No. 1 Januari 2018: 32-48;

PERBANDINGAN DAN TREND KINERJA KEUANGAN BPRS SELAMA LINKAGE PROGRAM

DENGAN BANK SYARIAH PERIODE 2011 - 2016 (STUDI KASUS BPRS BAKTIMAKMUR INDAH, BPRS

BHAKTI SUMEKAR, DAN BPRS PNM MENTARI)

deskriptif menyajikan nilai rata-rata

(mean), nilai terendah (minimum) dan nilai

tertinggi (maximum) dari rasio-rasio yang diujikan yaitu rasio ROA, ROE, BOPO, NPF, FDR, dan CAR yang dimiliki oleh BPRS yang menjadi sampel penelitian. Statistik deskriptif pada ini menggunakan program Ms.Excel 2010.

Teknik statistik inferensial digunakan untuk menganalisis data sampel dan hasilnya diberlakukan untuk populasinya (Anshori dan Iswati, 2009:123). Statistik inferensial dalam penelitian ini menggunakan analisis parametrik dengan Uji Anova dan juga analisis non parametrik dengan Uji Kruskal Wallis dengan menggunakan aplikasi SPSS 20.

\section{Hasil dan Pembahasan}

Setelah dilakukan analisis deskriptif dilanjutkan dengan melakukan analisis trend kinerja keuangan, uji normalitas, dan uji homogenitas yang menjadi persyaratan sebelum melakukan uji ANOVA (Santoso, 2013:278). Data uji normalitas dan homogenitas rasio Return On Asset (ROA), Return On Equity (ROE), Beban Operasional Pendapatan Operasional (BOPO), Non Performing Financing (NPF), Financing to Deposit Ratio (FDR), dan Capital Adequacy Ratio (CAR) pada BPRS Baktimakmur Indah, BPRS Bhakti Sumekar, dan BPRS PNM Mentari selama periode September 2011September 2016 dapat dilihat pada Tabel dibawah ini:

\begin{tabular}{|c|c|c|c|c|c|}
\hline $\begin{array}{l}\text { V } \\
\text { ar } \\
\text { ia } \\
\text { b } \\
\text { el }\end{array}$ & BPRS & Df & $\begin{array}{l}\text { Statis } \\
\text { tik }\end{array}$ & Sig & Ket \\
\hline \multirow{3}{*}{$\begin{array}{l}R \\
O \\
A\end{array}$} & Baktimakmur & 16 & 0,621 & 0,835 & Normal \\
\hline & $\begin{array}{c}\text { Bhakti } \\
\text { Sumekar }\end{array}$ & 16 & 0,793 & 0,556 & Normal \\
\hline & PNM Mentari & 16 & 0,604 & 0,858 & Normal \\
\hline \multirow{3}{*}{$\begin{array}{l}R \\
\mathrm{O} \\
\mathrm{E}\end{array}$} & Baktimakmur & 16 & 0,661 & 0,774 & Normal \\
\hline & $\begin{array}{c}\text { Bhakti } \\
\text { Sumekar }\end{array}$ & 16 & 0,476 & 0,977 & Normal \\
\hline & PNM Mentari & 16 & 0,587 & 0,881 & Normal \\
\hline \multirow{3}{*}{$\begin{array}{l}B \\
O \\
P \\
O\end{array}$} & Baktimakmur & 16 & 0,791 & 0,559 & Normal \\
\hline & $\begin{array}{c}\text { Bhakti } \\
\text { Sumekar }\end{array}$ & 16 & 0,715 & 0,686 & Normal \\
\hline & PNM Mentari & 16 & 0,806 & 0,535 & Normal \\
\hline \multirow{3}{*}{$\begin{array}{l}N \\
P \\
F\end{array}$} & Baktimakmur & 16 & 0,852 & 0,465 & Normal \\
\hline & $\begin{array}{c}\text { Bhakti } \\
\text { Sumekar }\end{array}$ & 16 & 0,842 & 0,477 & Normal \\
\hline & PNM Mentari & 16 & 0,538 & 0,934 & Normal \\
\hline \multirow{3}{*}{$\begin{array}{l}F \\
D \\
R\end{array}$} & Baktimakmur & 16 & 0,885 & 0,414 & Normal \\
\hline & $\begin{array}{c}\text { Bhakti } \\
\text { Sumekar }\end{array}$ & 16 & 0,610 & 0,851 & Normal \\
\hline & PNM Mentari & 16 & 0,667 & 0,765 & Normal \\
\hline \multirow{3}{*}{$\begin{array}{l}C \\
A \\
R\end{array}$} & Baktimakmur & 16 & 0,625 & 0,829 & Normal \\
\hline & $\begin{array}{l}\text { Bhakti } \\
\text { Sumekar }\end{array}$ & 16 & 0,719 & 0,679 & Normal \\
\hline & PNM Mentari & 16 & 1,483 & 0,025 & $\begin{array}{l}\text { Tidak } \\
\text { Normal }\end{array}$ \\
\hline
\end{tabular}

Sumber: hasil uji SPSS (data telah diolah)

Dari hasil uji normalitas menjelaskan bahwa untuk variabel CAR pada BPRS PNM Mentari memiliki nilai signifikansi 0,025 atau dibawah 0,05 sehingga dapat dinyatakan untuk variabel CAR pada BPRS PNM Mentari tidak terdistribusi normal. Sedangkan untuk variabel ROA, ROE, BOPO, NPF, dan FDR pada ketiga BPRS terkait memiliki nilai signifikansi diatas 0,05 sehingga dapat dinyatakan untuk variabel tersebut memiliki data yang terdistribusi normal.

Tabel 2

Tabel 1

Uji Normalitas 
Subagiyo, et al/Jurnal Ekonomi Syariah Teori dan Terapan Vol. 5 No. 1 Januari 2018: 32-48;

PERBANDINGAN DAN TREND KINERJA KEUANGAN BPRS SELAMA LINKAGE PROGRAM

DENGAN BANK SYARIAH PERIODE 2011 - 2016 (STUDI KASUS BPRS BAKTIMAKMUR INDAH, BPRS

BHAKTI SUMEKAR, DAN BPRS PNM MENTARI)

Uji Homogenitas

\begin{tabular}{|c|c|c|c|c|c|c|}
\hline $\begin{array}{l}\text { V } \\
\text { ar } \\
\text { ia } \\
\text { b } \\
\text { el }\end{array}$ & BPRS & $\begin{array}{l}\text { Lev } \\
\text { ene } \\
\text { Stati } \\
\text { stic }\end{array}$ & $\begin{array}{l}D \\
f \\
1\end{array}$ & $\begin{array}{l}D \\
f \\
2\end{array}$ & Sig & Ket \\
\hline \multirow{3}{*}{$\begin{array}{l}R \\
O \\
A\end{array}$} & Baktimakmur & \multirow{3}{*}{6,47} & \multirow{3}{*}{2} & \multirow{3}{*}{$\begin{array}{l}4 \\
5\end{array}$} & \multirow{3}{*}{$\begin{array}{c}0,00 \\
3\end{array}$} & \multirow{3}{*}{$\begin{array}{c}\text { Tidak } \\
\text { Homo } \\
\text { gen }\end{array}$} \\
\hline & $\begin{array}{l}\text { Bhakti } \\
\text { Sumekar }\end{array}$ & & & & & \\
\hline & PNM Mentari & & & & & \\
\hline \multirow{3}{*}{$\begin{array}{l}R \\
O \\
E\end{array}$} & Baktimakmur & \multirow{3}{*}{$\begin{array}{c}22,0 \\
8\end{array}$} & \multirow{3}{*}{2} & \multirow{3}{*}{$\begin{array}{l}4 \\
5\end{array}$} & \multirow{3}{*}{$\begin{array}{c}0,00 \\
0\end{array}$} & \multirow{3}{*}{$\begin{array}{c}\text { Tidak } \\
\text { Homo } \\
\text { gen }\end{array}$} \\
\hline & $\begin{array}{l}\text { Bhakti } \\
\text { Sumekar }\end{array}$ & & & & & \\
\hline & PNM Mentari & & & & & \\
\hline \multirow{3}{*}{$\begin{array}{l}B \\
O \\
P \\
O\end{array}$} & Baktimakmur & \multirow{3}{*}{$\begin{array}{c}19,6 \\
2\end{array}$} & \multirow{3}{*}{2} & \multirow{3}{*}{$\begin{array}{l}4 \\
5\end{array}$} & \multirow{3}{*}{$\begin{array}{c}0,00 \\
0\end{array}$} & \multirow{3}{*}{$\begin{array}{c}\text { Tidak } \\
\text { Homo } \\
\text { gen }\end{array}$} \\
\hline & Bhakti & & & & & \\
\hline & $\begin{array}{l}\text { Sumekar } \\
\text { PNM Mentari }\end{array}$ & & & & & \\
\hline \multirow{3}{*}{$\begin{array}{l}N \\
P \\
F\end{array}$} & Baktimakmur & \multirow{3}{*}{$\begin{array}{c}19,0 \\
1\end{array}$} & \multirow{3}{*}{2} & \multirow{3}{*}{$\begin{array}{l}4 \\
5\end{array}$} & \multirow{3}{*}{$\begin{array}{c}0,00 \\
0\end{array}$} & \multirow{3}{*}{$\begin{array}{c}\text { Tidak } \\
\text { Homo } \\
\text { gen }\end{array}$} \\
\hline & Bhakti & & & & & \\
\hline & $\begin{array}{l}\text { Sumekar } \\
\text { PNM Mentari }\end{array}$ & & & & & \\
\hline \multirow{4}{*}{$\begin{array}{l}F \\
D \\
R\end{array}$} & Baktimakmur & \multirow{4}{*}{0,98} & \multirow{4}{*}{2} & \multirow{4}{*}{$\begin{array}{l}4 \\
5\end{array}$} & \multirow{4}{*}{$\begin{array}{c}0,38 \\
3\end{array}$} & \multirow{4}{*}{$\begin{array}{c}\text { Homo } \\
\text { gen }\end{array}$} \\
\hline & Bhakti & & & & & \\
\hline & Sumekar & & & & & \\
\hline & PNM Mentari & & & & & \\
\hline \multirow{2}{*}{$\begin{array}{l}C \\
A \\
R\end{array}$} & Baktimakmur & \multirow[b]{2}{*}{3,77} & \multirow[b]{2}{*}{2} & \multirow[b]{2}{*}{$\begin{array}{l}4 \\
5\end{array}$} & \multirow[b]{2}{*}{$\begin{array}{c}0,03 \\
0\end{array}$} & \multirow{2}{*}{$\begin{array}{c}\text { Tidak } \\
\text { Homo } \\
\text { gen }\end{array}$} \\
\hline & $\begin{array}{l}\text { Bhakti } \\
\text { Sumekar }\end{array}$ & & & & & \\
\hline
\end{tabular}

Sumber: hasil uji SPSS (data telah diolah)

Dari hasil uji homogenitas menjelaskan bahwa untuk variabel FDR pada BPRS Baktimakmur Indah, BPRS Bhakti Sumekar, dan BPRS PNM Mentari memiliki signifikansi data 0,383 >0,05 sehingga dapat dinyatakan bahwa data tersebut homogen, dan dapat dilakukan uji Anova karena semua asumsi telah terpenuhi.

Pada variabel Return On Asset (ROA), Return On Equity (ROE), Beban Operasional Pendapatan Operasional (BOPO), Non Performing Financing (NPF) dan Capital Adequacy Ratio (CAR) pada ketiga BPRS terkait memiliki nilai signifikansi kurang dari 0,05 sehingga dapat dinyatakan bahwa data tersebut tidak homogen, dan dilakukan uji Kruskal Wallis.

\section{Uji Beda}

Uji Beda Return On Asset (ROA)
Tabel 3

Uji Beda ROA Kruskal Wallis

\begin{tabular}{|c|c|c|c|c|c|c|}
\hline $\begin{array}{c}\text { Va } \\
\text { ria } \\
\text { be } \\
\text { I }\end{array}$ & BPRS & $\begin{array}{c}\text { Me } \\
\text { an } \\
\text { Ran } \\
k\end{array}$ & $\begin{array}{l}\text { Chi } \\
\text { - } \\
\text { Squ } \\
\text { are }\end{array}$ & $\begin{array}{l}D \\
f\end{array}$ & Sig & Ket \\
\hline \multirow{3}{*}{$\begin{array}{l}R \\
O \\
A\end{array}$} & $\begin{array}{c}\text { Baktimakm } \\
\text { ur }\end{array}$ & $\begin{array}{c}23,9 \\
7 \\
\end{array}$ & \multirow{3}{*}{$\begin{array}{c}0,61 \\
8\end{array}$} & \multirow{3}{*}{2} & \multirow{3}{*}{$\begin{array}{l}0,7 \\
34\end{array}$} & \multirow{3}{*}{$\begin{array}{c}\mathbf{H}_{0} \\
\text { diteri } \\
\text { ma } \\
\text { (tidak } \\
\text { terda } \\
\text { pat } \\
\text { perbe } \\
\text { daan) }\end{array}$} \\
\hline & $\begin{array}{c}\text { Bhakti } \\
\text { Sumekar }\end{array}$ & $\begin{array}{c}22,8 \\
8 \\
\end{array}$ & & & & \\
\hline & $\begin{array}{c}\text { PNM } \\
\text { Mentari }\end{array}$ & $\begin{array}{c}26,6 \\
6\end{array}$ & & & & \\
\hline
\end{tabular}

Sumber: hasil uji SPSS (data telah diolah).

Berdasarkan tabel 3 hasil uji beda Kruskal Wallis yang dilakukan pada variabel ROA untuk BPRS Baktimakmur Indah, BPRS Bhakti Sumekar, dan BPRS PNM Mentari, diketahui bahwa nilai signifikansi dari variabel ini adalah sebesar 0,734 atau lebih besar dari 0,05. Pada tabel tersebut diketahui statistik hitung (chi-square) sebesar 0,618 dan statistik tabel dengan melihat tabel Chi-Square untuk df adalah 2 dan tingkat signifikansi sebesar 0,05 maka didapat statistik tabel sebesar 5,991. Keputusan dari uji Kruskal Wallis untuk variabel ROA adalah $\mathrm{H}_{0}$ diterima, atau dinyatakan tidak terdapat perbedaan dilihat dari sisi ROA antara ketiga BPRS tersebut karena nilai statistik hitung < statistik tabel yakni 0,618<5,991.

\section{Uji Beda Return On Equity (ROE)}

Tabel 4

Uji Beda ROE Kruskal Wallis Sumber: hasil uji SPSS (data telah diolah).

\begin{tabular}{|c|c|c|c|c|c|c|}
\hline $\begin{array}{l}\text { V } \\
\text { ari } \\
\text { ab } \\
\text { el }\end{array}$ & BPRS & $\begin{array}{c}\text { Me } \\
\text { an } \\
\text { Ran } \\
k\end{array}$ & $\begin{array}{c}\text { Chi } \\
- \\
\text { Squ } \\
\text { are }\end{array}$ & $\begin{array}{l}D \\
f\end{array}$ & Sig & Ket \\
\hline \multirow{3}{*}{$\begin{array}{l}R \\
O \\
E\end{array}$} & $\begin{array}{l}\text { Baktimakmu } \\
\text { r Indah }\end{array}$ & $\begin{array}{c}17,6 \\
3\end{array}$ & \multirow{3}{*}{$\begin{array}{c}23,5 \\
74\end{array}$} & \multirow{3}{*}{2} & \multirow{3}{*}{$\begin{array}{l}0,0 \\
00\end{array}$} & \multirow{3}{*}{$\begin{array}{c}\mathbf{H}_{\mathbf{0}} \\
\text { ditolak } \\
\text { (Terdap } \\
\text { at } \\
\text { perbed } \\
\text { aan) }\end{array}$} \\
\hline & $\begin{array}{l}\text { Bhakti } \\
\text { Sumekar }\end{array}$ & $\begin{array}{c}38,3 \\
8\end{array}$ & & & & \\
\hline & $\begin{array}{l}\text { PNM } \\
\text { Mentari }\end{array}$ & $\begin{array}{c}17,5 \\
0\end{array}$ & & & & \\
\hline
\end{tabular}


Subagiyo, et al/Jurnal Ekonomi Syariah Teori dan Terapan Vol. 5 No. 1 Januari 2018: 32-48;

PERBANDINGAN DAN TREND KINERJA KEUANGAN BPRS SELAMA LINKAGE PROGRAM

DENGAN BANK SYARIAH PERIODE 2011 - 2016 (STUDI KASUS BPRS BAKTIMAKMUR INDAH, BPRS

BHAKTI SUMEKAR, DAN BPRS PNM MENTARI)

Berdasarkan tabel 4 hasil uji beda

Kruskal Wallis yang dilakukan pada variabel ROE untuk BPRS Baktimakmur Indah, BPRS Bhakti Sumekar, dan BPRS PNM Mentari, diketahui bahwa nilai signifikansi dari variabel ini adalah 0,000 atau lebih kecil dari 0,05.

Pada tabel tersebut diketahui statistik hitung (chi-square) sebesar 23,574 dan statistik tabel dengan melihat tabel Chi-Square untuk df adalah 2 dan tingkat signifikansi sebesar 0,05 maka didapat statistic tabel sebesar 5,991. Keputusan dari uji Kruskal Wallis untuk variabel ROE adalah $\mathrm{H}_{0}$ ditolak, atau dinyatakan terdapat perbedaan kinerja keuangan dilihat dari sisi ROE pada ketiga BPRS tesebut karena nilai statistik hitung > statistik tabel yakni 23,574 > 5,991.

Uji Beda Beban Operasional Pendapatan Operasional (BOPO)

Tabel 5

Uji Beda BOPO Kruskal Wallis

\begin{tabular}{|c|c|c|c|c|c|c|}
\hline $\begin{array}{l}\text { V } \\
\text { ari } \\
\text { ab } \\
\text { el }\end{array}$ & BPRS & $\begin{array}{c}\text { Me } \\
\text { an } \\
\text { Ran } \\
k\end{array}$ & $\begin{array}{l}\text { Chi } \\
- \\
\text { Squ } \\
\text { are }\end{array}$ & $\begin{array}{l}D \\
f\end{array}$ & Sig & Ket \\
\hline \multirow{3}{*}{$\begin{array}{l}B \\
O \\
P \\
O\end{array}$} & $\begin{array}{l}\text { Baktimakm } \\
\text { ur Indah }\end{array}$ & $\begin{array}{c}33,6 \\
9\end{array}$ & \multirow{3}{*}{$\begin{array}{c}19,5 \\
96\end{array}$} & \multirow{3}{*}{2} & \multirow{3}{*}{$\begin{array}{l}0,0 \\
00\end{array}$} & \multirow{3}{*}{$\begin{array}{c}\mathbf{H}_{0} \\
\text { ditola } \\
\mathbf{k} \\
\text { (Terda } \\
\text { pat } \\
\text { perbe } \\
\text { daan) }\end{array}$} \\
\hline & $\begin{array}{l}\text { Bhakti } \\
\text { Sumekar }\end{array}$ & $\begin{array}{c}12,3 \\
8\end{array}$ & & & & \\
\hline & $\begin{array}{l}\text { PNM } \\
\text { Mentari }\end{array}$ & $\begin{array}{c}27,4 \\
4\end{array}$ & & & & \\
\hline
\end{tabular}

Sumber: hasil uji SPSS(data telah diolah)

Berdasarkan tabel 5 hasil uji beda

Kruskal Wallis yang dilakukan pada variabel BOPO untuk BPRS Baktimakmur Indah, BPRS Bhakti Sumekar, dan BPRS PNM Mentari, diketahui bahwa nilai signifikansi dari variabel ini adalah 0,000 atau lebih kecil dari 0,05. Pada tabel tersebut diketahui statistik hitung (chisquare) sebesar 19,596 dan statistik tabel dengan melihat tabel Chi-Square untuk df (derajat kebebasan) adalah 2 dan tingkat signifikansi sebesar 0,05 maka didapat statistik tabel sebesar 5,991. Keputusan dari uji Kruskal Wallis untuk variabel BOPO adalah $\mathrm{H}_{0}$ ditolak, atau dinyatakan terdapat perbedaan kinerja keuangan dilihat dari sisi BOPO untuk ketiga BPRS tesebut karena nilai statistik hitung > statistik tabel yakni 19,596 > 5,991.

Uji Beda Non Performing Financing (NPF)

Tabel 6

Uji Beda NPF Kruskal Wallis

\begin{tabular}{|c|c|c|c|c|c|c|}
\hline $\begin{array}{c}\text { Var } \\
\text { iab } \\
\text { el }\end{array}$ & BPRS & $\begin{array}{c}\text { Me } \\
\text { an } \\
\text { Ran } \\
k\end{array}$ & $\begin{array}{c}\text { Chi } \\
- \\
\text { Squ } \\
\text { are }\end{array}$ & $\begin{array}{l}D \\
f\end{array}$ & Sig & Ket \\
\hline \multirow{3}{*}{$\begin{array}{c}\mathrm{NP} \\
\mathrm{F}\end{array}$} & $\begin{array}{l}\text { Baktimakmur } \\
\text { Indah }\end{array}$ & $\begin{array}{c}36,0 \\
6\end{array}$ & \multirow{3}{*}{$\begin{array}{c}16,3 \\
78\end{array}$} & \multirow{3}{*}{2} & \multirow{3}{*}{$\begin{array}{l}0,0 \\
00\end{array}$} & \multirow{3}{*}{$\begin{array}{c}\mathbf{H}_{\mathbf{0}} \\
\text { ditola } \\
\mathbf{k} \\
\text { (Terd } \\
\text { apat } \\
\text { perbe } \\
\text { daan) }\end{array}$} \\
\hline & Bhakti & 18,9 & & & & \\
\hline & PNM Mentari & $\begin{array}{c}18,5 \\
0\end{array}$ & & & & \\
\hline
\end{tabular}

Sumber: hasil uji SPSS (data telah diolah)

Berdasarkan tabel 6 hasil uji beda

Kruskal Wallis yang dilakukan pada variabel NPF untuk BPRS Baktimakmur Indah, BPRS Bhakti Sumekar, dan BPRS PNM Mentari, diketahui bahwa nilai signifikansi dari variabel ini adalah 0,000 atau lebih kecil dari 0,05. Pada tabel tersebut diketahui statistik hitung (chisquare) sebesar 16,378 dan statistik tabel dengan melihat tabel Chi-Square untuk df adalah 2 dan tingkat signifikansi sebesar 0,05 maka didapat statistik tabel sebesar 5,991. Keputusan dari uji Kruskal Wallis untuk variabel NPF adalah $\mathrm{H}_{0}$ ditolak, atau terdapat perbedaan kinerja keuangan dilihat dari rasio NPF karena nilai statistik 
Subagiyo, et al/Jurnal Ekonomi Syariah Teori dan Terapan Vol. 5 No. 1 Januari 2018: 32-48;

PERBANDINGAN DAN TREND KINERJA KEUANGAN BPRS SELAMA LINKAGE PROGRAM

DENGAN BANK SYARIAH PERIODE 2011 - 2016 (STUDI KASUS BPRS BAKTIMAKMUR INDAH, BPRS

BHAKTI SUMEKAR, DAN BPRS PNM MENTARI)

hitung > statistik tabel yakni 16,378

$>5,991$.

Uji Beda Financing to Deposit Ratio (FDR)

Tabel 7

Uji Beda FDR ANOVA

\begin{tabular}{|c|c|c|c|c|c|}
\hline $\begin{array}{l}\text { Va } \\
\text { ria } \\
\text { bel }\end{array}$ & BPRS & $\begin{array}{l}D \\
f\end{array}$ & $F$ & Sig & Ket \\
\hline \multirow{3}{*}{$\begin{array}{l}\mathrm{FD} \\
\mathrm{R}\end{array}$} & $\begin{array}{l}\text { Baktimakmur } \\
\text { Indah }\end{array}$ & \multirow{3}{*}{2} & \multirow{3}{*}{$\begin{array}{c}5,47 \\
0\end{array}$} & \multirow{3}{*}{$\begin{array}{l}0,0 \\
07\end{array}$} & \multirow{3}{*}{$\begin{array}{c}\text { Ho ditolak } \\
\text { (Terdapat } \\
\text { Perbeda } \\
\text { an) }\end{array}$} \\
\hline & $\begin{array}{c}\text { Bhakti } \\
\text { Sumekar }\end{array}$ & & & & \\
\hline & PNM Mentari & & & & \\
\hline
\end{tabular}

Sumber: uji beda SPSS (data telah diolah)

Berdasarkan tabel 7 hasil uji beda Anova yang dilakukan pada variabel FDR untuk BPRS Baktimakmur Indah, BPRS Bhakti Sumekar, dan BPRS PNM Mentari, diketahui bahwa df adalah 2 dan nilai signifikansi dari variabel ini adalah 0,007 atau lebih kecil dari 0,05. Pada tabel tersebut diketahui F output sebesar 5,470, sedangkan $F$ tabel yang didapat dari tabel F dengan Numerator adalah (jumlah variabel shift-1), atau 3-1 = 2, dan Denumerator $=$ (jumlah kasus-jumlah variabel shift), atau 48-3 $=45$, dari tabel $F$, didapat angka 3,20 . Sehingga dapat disimpulkan bahwa rata-rata FDR dari ketiga BPRS linkage program memang berbeda karena memiliki $\mathrm{F}$ output $>\mathrm{F}$ tabel, yaitu 5,470 >3,20.

Uji Beda Capital Adequacy Ratio (CAR)

Tabel 8

Uji Beda CAR Kruskal Wallis

\begin{tabular}{|c|c|c|c|c|c|c|}
\hline $\begin{array}{c}\text { Varia } \\
\text { bel }\end{array}$ & BPRS & $\begin{array}{c}\text { Mea } \\
n \\
\text { Rank }\end{array}$ & $\begin{array}{c}\text { Chi- } \\
\text { Squa } \\
\text { re }\end{array}$ & $\begin{array}{l}D \\
f\end{array}$ & Sig & Ket \\
\hline \multirow{3}{*}{ CAR } & $\begin{array}{l}\text { Baktimak } \\
\text { mur }\end{array}$ & 39,19 & \multirow{3}{*}{$\begin{array}{c}35,67 \\
9\end{array}$} & \multirow{3}{*}{2} & \multirow{3}{*}{$\begin{array}{l}0,0 \\
00\end{array}$} & \multirow{3}{*}{$\begin{array}{c}\mathrm{H}_{0} \\
\text { ditolak } \\
\text { (beda) }\end{array}$} \\
\hline & $\begin{array}{l}\text { Bhakti } \\
\text { Sumekar }\end{array}$ & 24,69 & & & & \\
\hline & $\begin{array}{l}\text { PNM } \\
\text { Mentari }\end{array}$ & 9,63 & & & & \\
\hline
\end{tabular}

Sumber: hasil uji SPSS (data telah diolah)

Berdasarkan tabel 8 hasil uji beda Kruskal Wallis yang dilakukan pada variabel CAR untuk BPRS Baktimakmur Indah, BPRS Bhakti Sumekar, dan BPRS PNM Mentari, diketahui bahwa nilai signifikansi dari variabel ini adalah 0,000 atau lebih kecil dari 0,05. Pada tabel tersebut diketahui statistik hitung (chisquare) sebesar 35,679 dan statistik tabel dengan melihat tabel Chi-Square untuk df (derajat kebebasan) adalah 2 dan tingkat signifikansi sebesar 0,05 maka didapat statistik tabel sebesar 5,991. Keputusan dari uji Kruskal Wallis untuk variabel CAR adalah $\mathrm{H}_{0}$ ditolak, atau dinyatakan terdapat perbedaan kinerja kevangan dilihat dari sisi CAR untuk ketiga BPRS tesebut karena nilai statistik hitung > statistik tabel yakni 35,679 > 5,991.

\section{Pembahasan}

Berdasarkan hasil uji beda menggunakan Anova dan Kruskal Wallis test yang telah dilakukan sebelumnya, maka hasil yang didapatkan untuk semua variabel yaitu ROA, ROE, BOPO, NPF, FDR, dan CAR adalah sebagai berikut: 
Subagiyo, et al/Jurnal Ekonomi Syariah Teori dan Terapan Vol. 5 No. 1 Januari 2018: 32-48;

PERBANDINGAN DAN TREND KINERJA KEUANGAN BPRS SELAMA LINKAGE PROGRAM DENGAN BANK SYARIAH PERIODE 2011 - 2016 (STUDI KASUS BPRS BAKTIMAKMUR INDAH, BPRS BHAKTI SUMEKAR, DAN BPRS PNM MENTARI)

Tabel 9

Hasil Uji Beda Semua Variabel BPRS Linkage program

\begin{tabular}{|c|c|c|}
\hline Var & Hasil Uji Beda & Keterangan \\
\hline ROA & $H_{0}$ diterima & $\begin{array}{c}\text { Tidak Terdapat } \\
\text { Perbedaan }\end{array}$ \\
\hline ROE & $\mathrm{H}_{0}$ ditolak & Terdapat Perbedaan \\
\hline BOPO & $\mathrm{H}_{0}$ ditolak & Terdapat Perbedaan \\
\hline NPF & $\mathrm{H}_{0}$ ditolak & Terdapat Perbedaan \\
\hline FDR & $\mathrm{H}_{0}$ ditolak & Terdapat Perbedaan \\
\hline CAR & $\mathrm{H}_{0}$ ditolak & Terdapat Perbedaan \\
\hline
\end{tabular}

Sumber: Hasil Uji Beda Anova dan Kruskal Wallis

\section{Return On Asset (ROA)}

Hasil uji Kruskal Wallis yang telah dilakukan, dapat dinyatakan bahwa dari ketiga kategori BPRS linkage program yaitu BPRS Baktimakmur Indah, BPRS Bhakti Sumekar, dan BPRS PNM Mentari periode September 2011-September 2016, dinyatakan tidak terdapat perbedaan kinerja kevangan dari segi rasio ROA karena memiliki nilai signifikansi sebesar $0,734>0,05$ dan nilai chi square sebesar $0,618<5,991$ (nilai tabel).

Pada grafik 4.1 halaman 77 dapat diketahui bahwa perkembangan nilai rasio ROA pada BPRS Baktimakmur Indah dan BPRS Bhakti Sumekar menunjukkan peningkatan garis linier setiap triwulannya jika dibandingkan dengan garis linier yang dimiliki oleh BPRS PNM Mentari yang cenderung menunjukkan penurunan setiap triwulannya. Namun, rata-rata nilai ROA dari ketiga BPRS masih dikategorikan baik karena berada diatas 1,25\%.

Hal ini mengindikasikan bahwa linkage program dapat memberikan dampak positif secara keseluruhan dilihat dari sisi ROA masing-masing BPRS. Meskipun terjadi penurunan trendline, namun penurunannya masih dalam kategori baik dan nilai rara-rata ROA masih berada diatas 1,25\%.

Tidak adanya perbedaan kinerja keuangan dapat terjadi karena memiliki nilai rata-rata ROA yang cenderung sama, peningkatan laba operasional tidak diiringi oleh penambahan aset dari masingmasing BPRS, terlihat dari jumlah aset tetap dan inventaris yang dimiliki oleh masing-masing BPRS tidak mengalami peningkatan yang signifikan meskipun laba operasional yang didapatkan BPRS tersebut meningkat.

Pihak BPRS cenderung menyimpan laba operasionalnya dalam bentuk ekuitas, dan menyalurkannya kembali sebagai pembiayaan yang ditunjukkan dengan meningkatnya nilai pembiayaan yang berakibat meningkatkan total aset secara keseluruhan. Kondisi rata-rata NPF dari ketiga BPRS linkage program yang melebihi batas wajar yang ditentukan oleh Bl yaitu kurang dari 5\%. Dapat diproyeksikan pada periode tersebut terdapat beberapa pembiayaan bermasalah yang dihadapi oleh masingmasing pihak BPRS yang menyebabkan BPRS linkage program tidak dapat memaksimalkan keuntungan yang didapat untuk menambah aset.

\section{Return On Equity (ROE)}

Hasil uji Kruskal Wallis yang telah dilakukan, dapat dinyatakan bahwa dari ketiga BPRS linkage program yaitu BPRS Baktimakmur Indah, BPRS Bhakti Sumekar, dan BPRS PNM Mentari periode September 2011-September 2016, dinyatakan 
Subagiyo, et al/Jurnal Ekonomi Syariah Teori dan Terapan Vol. 5 No. 1 Januari 2018: 32-48;

PERBANDINGAN DAN TREND KINERJA KEUANGAN BPRS SELAMA LINKAGE PROGRAM DENGAN BANK SYARIAH PERIODE 2011 - 2016 (STUDI KASUS BPRS BAKTIMAKMUR INDAH, BPRS BHAKTI SUMEKAR, DAN BPRS PNM MENTARI) terdapat perbedaan kinerja keuangan dari segi rasio ROE karena memiliki nilai signifikansi sebesar $0,000<0,05$ dan nilai chi-square sebesar 23,574>5,991 (nilai tabel).

Pada grafik 4.2 dapat diketahui bahwa perkembangan ROE pada BPRS Bhakti Sumekar menunjukkan peningkatan garis linier setiap triwulannya jika dibandingkan dengan garis linier yang dimiliki oleh BPRS Baktimakmur Indah dan BPRS PNM Mentari yang cenderung menunjukkan penurunan garis linier setiap triwulannya. Hal tesebut menunjukkan bahwa BPRS Bhakti Sumekar memiliki kinerja terbaik dilihat dari sisi ROE dibandingkan BPRS lainnya. Hal ini mengindikasikan bahwa linkage program dapat memberikan dampak positif bagi masing-masing BPRS dilihat dari rasio ROE.

Perbedaan ROE pada ketiga BPRS linkage program tersebut dapat terlihat dari perbedaan nilai rata-rata ROE yang cukup signifikan pada BPRS Bhakti Sumekar. Adanya perbedaan pada jumlah modal yang cukup signifikan, diindikasi menjadikan BPRS Bhakti Sumekar memiliki potensi menyalurkan pembiayaan lebih luas dan dengan jumlah yang cukup besar, yang mengakibatkan laba yang didapatkan juga lebih besar dibandingkan BPRS Baktimakmur Indah dan BPRS PNM Mentari. Hal tersebut mengindikasikan penyebab adanya perbedaan kinerja dari BPRS Bhakti Sumekar dengan BPRS

Baktimakmur Indah dan BPRS PNM Mentari selama menggunakan linkage program.

\section{Beban Operasional Pendapatan Operasional (BOPO)}

Hasil uji Kruskal Wallis yang telah dilakukan, dapat dinyatakan bahwa dari ketiga BPRS linkage program yaitu BPRS Baktimakmur Indah, BPRS Bhakti Sumekar, dan BPRS PNM Mentari periode September 2011-September 2016, dinyatakan terdapat perbedaan kinerja keuangan dari segi rasio BOPO karena memiliki nilai signifikansi sebesar 0,000 0,05 dan nilai chi-square sebesar 19,596>5,991 (nilai tabel).

Pada grafik 4.3 dapat diketahui bahwa perkembangan BOPO pada BPRS Baktimakmur Indah menunjukkan penurunan garis linier setiap triwulannya jika dibandingkan dengan garis linier yang dimiliki oleh BPRS Bhakti Sumekar dan BPRS PNM Mentari yang cenderung menunjukkan peningkatan meskipun tidak terlalu signifikan. Namun BPRS Baktimakmur Indah memiliki nilai rata-rata BOPO tertinggi dibandingkan dengan BPRS Bhakti Sumekar dan BPRS PNM Mentari periode September 2011September 2016.

Kondisi nilai rata-rata BOPO yang masih kurang dari $85 \%$ mengindikasikan bahwa linkage program dapat memberikan dampak positif bagi masingmasing BPRS dilihat dari rasio BOPO, dan dalam mengelola biaya operasionalnya masih dalam kategori baik dan efisien. 
Subagiyo, et al/Jurnal Ekonomi Syariah Teori dan Terapan Vol. 5 No. 1 Januari 2018: 32-48;

PERBANDINGAN DAN TREND KINERJA KEUANGAN BPRS SELAMA LINKAGE PROGRAM

DENGAN BANK SYARIAH PERIODE 2011 - 2016 (STUDI KASUS BPRS BAKTIMAKMUR INDAH, BPRS

BHAKTI SUMEKAR, DAN BPRS PNM MENTARI)

Perbedaan kinerja BPRS dari sisi

rasio BOPO dari ketiga BPRS tersebut

diindikasi karena adanya peningkatan

biaya hidup yang semakin tinggi dan

adanya perbedaan biaya hidup antara satu wilayah dengan wilayah lainnya, serta kondisi ekonomi yang tidak stabil sehingga beban operasional yang harus dikeluarkan BPRS untuk membiayai karyawan dan operasionalnya semakin meningkat yang diindikasi menjadi faktor penyebab adanya peningkatan beban operasional yang dialami oleh ketiga BPRS linkage program.

\section{Non Performing Financing (NPF)}

Hasil uji Kruskal Wallis yang telah dilakukan, dapat dinyatakan bahwa ketiga BPRS linkage program yaitu BPRS Baktimakmur Indah, BPRS Bhakti Sumekar, dan BPRS PNM Mentari periode September 2011-September 2016, dinyatakan terdapat perbedaan kinerja keuangan dari segi rasio NPF karena memiliki nilai signifikansi sebesar 0,000 0,05 dan nilai chi-square sebesar 16,378 > 5,991 (nilai tabel).

Pada grafik 4.4 dapat diketahui bahwa perkembangan NPF pada BPRS Bhakti Sumekar memiliki kinerja yang baik karena nilai garis linier NPF yang cenderung menurun setiap triwulannya dibandingkan dengan BPRS lainnya. BPRS PNM Mentari memiliki kinerja yang cukup baik dalam mengelola rasio NPF karena memiliki nilai rata-rata trend NPF yang peningkatannya tidak terlalu signifikan, namun masih memiliki Trendline yang

cenderung meningkat. BPRS Baktimakmur Indah cenderung mengalami peningkatan nilai trend dan trendline rasio NPF selama periode September 2011September 2016. BPRS Baktimakmur Indah memiliki nilai NPF tertinggi yakni 10,61\%, nilai tersebut menunjukkan kondisi pembiayaan bermasalah yang bermasalah atau tidak sehat.

Hal ini mengindikasikan bahwa linkage program dapat memberikan dampak positif bagi BPRS Bhakti Sumekar, dan BPRS PNM Mentari. Hal tersebut dikarenakan tingkat NPF dari BPRS Bhakti Sumekar dan BPRS PNM Mentari yang masih kurang dari $5 \%$ dan menunjukkan nilai rata-rata NPF yang semakin menurun setiap triwulannya yang mengindikasikan kinerja BPRS dalam mengelola pembiayaan bermasalahnya yang semakin baik. Namun, linkage program belum dapat memberikan dampak positif bagi BPRS Baktimakmurlndah, karena meskipun telah diberikan dana linkage tingkat NPF cenderung mengalami peningkatan hingga mencapai nilai ratarata sebesar 10,61\%.

Hal tersebut dipengaruhi oleh kondisi usaha debitur dari BPRS Baktimakmur Indah kurang baik, dan juga adanya musibah lumpur lapindo Sidoarjo yang menyebabkan kondisi masyarakat Sidoarjo mengalami penurunan dari segi ekonomi. Selain itu, Account Officer (AO) yang sangat terbatas, yakni kurang lebih 2 orang yang dimiliki BPRS Baktimakmur Indah, diindikasi menyebabkan tingginya 
Subagiyo, et al/Jurnal Ekonomi Syariah Teori dan Terapan Vol. 5 No. 1 Januari 2018: 32-48;

PERBANDINGAN DAN TREND KINERJA KEUANGAN BPRS SELAMA LINKAGE PROGRAM DENGAN BANK SYARIAH PERIODE 2011 - 2016 (STUDI KASUS BPRS BAKTIMAKMUR INDAH, BPRS BHAKTI SUMEKAR, DAN BPRS PNM MENTARI) tingkat NPF karena proses seleksi debitur kurang maksimal.

\section{Financing to Deposit Ratio (FDR)}

Hasil uji Anova yang telah dilakukan, dapat dinyatakan bahwa ketiga BPRS linkage program yaitu BPRS Baktimakmur Indah, BPRS Bhakti Sumekar, dan BPRS PNM Mentari periode September 2011-September 2016, dinyatakan terdapat perbedaan kinerja keuangan dari segi FDR karena memiliki nilai signifikansi sebesar 0,007 $<0,05$ dan $F$ output sebesar 5,470 > 3,20 ( $F$ tabel).

Pada grafik 4.5 dapat diketahui bahwa perkembangan FDR pada BPRS Baktimakmur Indah memiliki garis linier FDR yang cenderung mengalami peningkatan setiap triwulannya dibandingkan dengan BPRS lainnya. BPRS Bhakti Sumekar dan BPRS PNM Mentari mengalami penurunan rata-rata nilai garis linier Financing to Deposit Ratio (FDR).

Hal ini mengindikasikan bahwa linkage program dapat memberikan dampak positif bagi BPRS Bhakti Sumekar. Hal tersebut dikarenakan tingkat FDR dari BPRS Bhakti Sumekar memiliki nilai ratarata FDR $84,18 \%$ dan memiliki kecenderungan menurun setiap triwulannya, yang berarti BPRS Bhakti Sumekar memiliki kinerja yang baik dalam menjaga likuiditasnya dan mengembalikan dana dari nasabah saat nasabah menarik dananya dengan menganadalkan pembiayaan sebagai sumber likuiditasnya. Namun, linkage program belum memberikan dampak positif bagi BPRS Baktimakmur Indah dan BPRS PNM Mentari karena masih memiliki nilai rata-rata rasio FDR yang lebih dari 85\% dan memiliki kecenderungan mengalami peningkatan nilai rasio FDR selama periode September 2011September 2016.

\section{Capital Adequacy Ratio (CAR)}

Hasil uji Kruskal Wallis yang telah dilakukan, dapat dinyatakan bahwa dari ketiga BPRS linkage program dinyatakan terdapat perbedaan kinerja keuangan dari segi rasio CAR karena memiliki nilai signifikansi sebesar 0,000 0,05 dan nilai chi-square sebesar $35,679>5,991$ (nilai tabel).

Pada gambar 4.6 dapat diketahui bahwa perkembangan CAR pada BPRS Baktimakmur Indah, BPRS Bhakti Sumekar, dan BPRS PNM Mentari menunjukkan penurunan garis linier setiap triwulannya, namun masih dalamkategori sangat baik karena nilai rasio CAR berada jauh diatas nilai $8 \%$. Hal tersebut menunjukkan bahwa ketiga BPRS linkage memiliki kinerja keuangan yang baik dilihat dari sisi CAR.

$\mathrm{Hal}$ ini mengindikasikan bahwa linkage program dapat memberikan dampak positif bagi BPRS Baktimakmur Indah, BPRS Bhakti Sumekar, dan BPRS PNM Mentari. Hal tersebut dikarenakan tingkat CAR dari ketiga BPRS tersebut memiliki nilai rata-rata CAR $66,52 \%$, yang berarti bahwa ketiga BPRS tersebut memiliki tingkat kecukupan modal yang baik untuk mengatasi setiap resiko yang dihadapi. 
Subagiyo, et al/Jurnal Ekonomi Syariah Teori dan Terapan Vol. 5 No. 1 Januari 2018: 32-48;

PERBANDINGAN DAN TREND KINERJA KEUANGAN BPRS SELAMA LINKAGE PROGRAM

DENGAN BANK SYARIAH PERIODE 2011 - 2016 (STUDI KASUS BPRS BAKTIMAKMUR INDAH, BPRS

BHAKTI SUMEKAR, DAN BPRS PNM MENTARI)

\section{Simpulan}

Berdasarkan hasil penelitian dan pembahasan yang telah dilakukan mengenai perkembangan tren dan perbandingan kinerja keuangan BPRS Baktimakmur Indah, BPRS Bhakti Sumekar, dan BPRS PNM Mentari selama menggunakan linkage program dilihat dari rasio ROA, ROE, BOPO, NPF, FDR, dan CAR maka kesimpulan yang dapat diambil adalah:

1. Berdasarkan analisis trend kinerja keuangan periode 30 September 2011 30 September 2016 yang dilakukan, perkembangan pada rasio ROA, ROE, BOPO, NPF, FDR yang dimiliki oleh BPRS Bhakti Sumekar memiliki kinerja yang paling baik jika dibandingkan dengan BPRS lainnya. Namun, pada perkembangan rasio CAR BPRS Baktimakmur Indah memiliki perkembangan nilai trend rasio CAR yang paling baik. Sehingga dapat disimpulkan bahwa BPRS Bhakti Sumekar memiliki kinerja terbaik dalam mengelola dana linkage dan dapat dijadikan standart BPRS yang baik dalam mengelola dana linkage. Selain itu, BPRS Bhakti Sumekar juga dapat digunakan sebagai referensi bagi pihak pengambil kebijakan untuk pengelolaan linkage program yang baik pada BPRS.

2. Berdasarkan uji beda menggunakan ANOVA dan Kruskal Wallis test pada BPRS Baktimakmur Indah, BPRS Bhakti Sumekar, dan BPRS PNM Mentari dinyatakan bahwa terdapat perbedaan signifikan pada rasio ROE, BOPO, NPF, FDR, dan CAR, sedangkan pada rasio ROA pada ketiga BPRS linkage program dinyatakan tidak terdapat perbedaan kinerja kevangan.

\section{DAFTAR PUSTAKA}

Anshori, Muslich dan Iswati. 2009. Metodologi Penelitian Kuantitatif. Surabaya: Airlangga University Press.

Bank Indonesia. 2001. Lampiran Surat Edaran BI No. 3/30/DPNP Perihal Sistem Penilaian Tingkat Kesehatan Bank Umum Berdasarkan Prinsip Syariah. Jakarta: Bank Indonesia 2004. Arsitektur Perbankan Indonesia (API)

Linkage program

2007. Lampiran Surat Edaran No. 9/24/DPbS Perihal Sistem Penilaian Tingkat Kesehatan Bank Umum Berdasarkan Prinsip Syariah. Jakarta: Bank Indonesia

Kevangan BPRS. (online). (www.bi.go.id, diakses 23 Oktober 2016)

Dendawijaya, Lukman. 2005. Manajemen Perbankan, Edisi Kedua, Cetakan Kedua. Bogor: Ghalia Indonesia.

Ismail. 2011. Perbankan Syariah. Jakarta: Kencana Media Group

Ismail. 2014. Sejarah Perkembangan BPRSyariah di Indonesia. (online), (http://ismail 125cc.blogspot.co.id diakses 16 September 2016) 
Subagiyo, et al/Jurnal Ekonomi Syariah Teori dan Terapan Vol. 5 No. 1 Januari 2018: 32-48;

PERBANDINGAN DAN TREND KINERJA KEUANGAN BPRS SELAMA LINKAGE PROGRAM

DENGAN BANK SYARIAH PERIODE 2011 - 2016 (STUDI KASUS BPRS BAKTIMAKMUR INDAH, BPRS

BHAKTI SUMEKAR, DAN BPRS PNM MENTARI)

Kasmir. 2013. Analisis Laporan Kevangan.

Jakarta: PT Raja Grafindo

Persada.

Mahmudi. 2010. Analisa Laporan Keuangan Pemerintah Daerah. Yogyakarta: STIM YKPN

Republik Indonesia. 2008. Undang-Undang Nomor 21 Tahun 2008 Tentang Perbankan Syariah. Jakarta: Republik Indonesia

Republik Indonesia. 2009. Peraturan Nomor : 03/Per/M.KUKM/III/2009 Menteri Negara Koperasi Dan Usaha Kecil Menengah Nomor 03/PER/M.KUKM/III/2009 Tentang Linkage program. Jakarta: Republik Indonesia

Rivai, Veithzal dan Arifin. 2008. Islamic Banking Sebuah Teori, Konsep, dan Aplikasi. Jakarta: Bumi Aksara.

Santoso, Singgih. 2013. Menguasai SPSS di Era Informasi. Jakarta: Elex Media Komputindo. 